\title{
ACADEMIC STRESS IS ASSOCIATED WITH EMOTIONAL EATING BEHAVIOR AMONG ADOLESCENT
}

\author{
Nadia Ramadhani ${ }^{1 *}$, Trias Mahmudiono ${ }^{1}$ \\ ${ }^{1}$ Department of Nutrition, Faculty of Public Health, Universitas Airlangga, Indonesia \\ *E-mail: nadia.ramadhani-2015@fkm.unair.ac.id
}

\begin{abstract}
Academic stress is one of the sources of stress factor among adolescent. Stress condition will trigger cortisol reaction process which associated with unhealthy eating behavior. Emotional eating is an eating behavior in response to stimulation of negative emotion. This study aims to analyze the association between academic stress with emotional eating behavior among adolescent at SMAN 6 Surabaya. This study used a cross sectional design. Samples were obtained using Cluster Random Sampling techniques with total sample of 133 people. Data were collected using the Educational Stress Scale for Adolescent (ESSA), Dutch Eating Behavior Questionnaire (DEBQ) and Food Frequency Questionnaire (FFQ). Kolmogorov-Smirnov was used to determine the normality of data obtained. Association between variables was analyzed using Spearman correlation. The results showed that $47,4 \%$ students experienced moderate academic stress and $51,1 \%$ of students experienced emotional eating. There was significant association between academic stress with emotional eating behavior $(\mathrm{p}=0.003$ ). Emotional eating behavior was positively correlated with consumption of fast food or canned food, sweet food or cakes, dairy products and sweet beverages.
\end{abstract}

Keywords: emotional eating behavior, adolescent, academic stress

\section{INTRODUCTION}

Adolescence is a critical period of biological, emotional and psychological development, as well as social. During this period a person becomes an independent individual, forms new relationships, develops social skills, and learns behaviors that will last for the rest of life. This period can also be one of the most challenging (WHO, 2018). Teenagers are often faced with emotional and behavioral problems including anxiety, depression, self-harm and eating disorders (Murdoch Children's Research Institute, 2015). There are four sources of emotional problems in adolescents, namely intrapersonal, interpersonal, academic, and environmental. Compared to other sources of stress, sources of academic stress are the most significant in adolescents. Perceived stress such as lower scores than expectations, fear or anxiety facing exams, high workload in class, and too many lessons (Akande, et al., 2014).

Senior High School is an important stage for students, because it begins to determine the subject area as desired. The results of learning, i.e., values, become a factor of consideration in being able to be in the desired subject area. This makes adolescents under pressure to get grades as expected. In addition, there is also a feeling of pressure because they face difficulties in understanding subjects that are definitely more difficult and have broader content to study than junior high school students (Subramani and Kadhiravan, 2017; Sripongwiwat, et al., 2018). Conditions in which students are unable to face academic demands and perceive existing demands as distractions are the definition of academic stress (Sayekti, 2017). Subramani and Kadhiravan's (2017) research shows the results of academic stress and mental health are significantly correlated with each other.

In short term, stress triggers a decrease in appetite. The hypothalamus in the brain will give a message to the adrenal glands to pump the epinephrine hormone which helps trigger the body's response to delay eating (Harvard, 2018). However, if the stress condition continues or persists, adrenals will increase cortisol in the bloodstream which can trigger an increase in appetite (Finch and Tomiyama, 2015). Stress conditions are also associated with emotional eating and unhealthy eating patterns (Tahir, 2016). In addition, emotional eating behavior is also related to stress factors that come from academic performance (Kim and Kye, 2017). Emotional 
eating behavior is eating behavior in response to negative emotional stimulation. This is done as an effort to coping with negative emotions, but will have a dangerous impact on physical, emotional and self-esteem (NEDA, 2004). The physical impact that can be seen is the change in body weight which can affect the nutritional status of adolescents.

Nutritional status is an indicator that can be used to assess a person's health status. Nutritional status can be determined using the Body Mass Index (BMI) through height and weight. Research done by Purwanti, et al. (2017) found that the higher the level of stress, the higher the BMI value. A high BMI value from the normal category indicates that someone is over nutrition or overweight. Stress that occurs among adolescents can lead to the development of obesity, which is a worldwide public health problem in adulthood (Tajik, et al., 2016). Therefore, this study aims to analyze the relationship between academic stress and emotional eating behavior in adolescents at SMAN 6 Surabaya.

\section{METHOD}

This was an observational study using a cross sectional design. The research was conducted at SMAN 6 Surabaya in February-April 2019. Samples were obtained through cluster random sampling technique as many as 133 students. The total population was 614 students who were students in grades 10 and 11 aged 15-17 years with 308 students coming from grade 10 and 306 students from class 11 . The total number of clusters in the study was 17 clusters. Then from several clusters randomly selected to be the research subjects or representatives of the population (Fig. 1). The inclusion criteria are adolescents aged 15-17 years, active students who attend SMAN 6 Surabaya and the exclusion criteria are adolescents who are on a diet, use assistive devices such as wheelchairs, or who cannot stand up to have their weight and height measured, as well as those who are sick or suffering from certain diseases.

The independent variable in this study is academic stress, while the dependent variable is emotional eating behavior and frequency of food consumption. Anthropometric measurements were carried out with the Elitech ${ }^{\circledR}$ digital bathroom scale with an accuracy of 0.1 to measure body weight and a stadiometer to measure height. The anthropometric data obtained were then analyzed using WHO AnthroPlus ${ }^{\circledR}$, in order to obtain a z-score value to determine BMI / Age (Body Mass Index based on Age) for adolescents. The z-score was categorized according to the BMI / Age cut off point for 5-18 years age group (Indonesia $\mathrm{MoH}$, 2011). The Educational Stress Scale for Adolescent (ESSA) questionnaire was used to determine adolescent academic stress data. The questionnaire consisted of 16 question items using a 5-point Likert scale with answers to strongly disagree to strongly agree and classified into high (score $>58$ ), moderate (score 51-58), and low (score $<50$ ) (Sun, et al., 2011). The Cronbach alpha for a total of 16 items on the ESSA scale was 0.81 which indicates good internal consistency.

Emotional eating behavior was measured using 13 question items, the Dutch Eating Behavior Questionnaire (DEBQ). DEBQ is a self-reported questionnaire that has strong psychometric properties. The use of DEBQ has been supported in clinical and nonclinical samples, from various weight categories (normal, overweight, and obese). Responses are given through a 5-point Likert scale with details of 1 (never), 2 (rarely), 3 (sometimes), 4 (often) and 5 (very often). The score is obtained from the total number of responses from each question item which is then categorized as emotional eating if $\geq$ median and not emotional eating if the score is <median (Strien, et al., 1986). This questionnaire has been used in research in Indonesia and tested for reliability and obtained a Cronbach alpha coefficient value of 0.846 (very high) (Khotibuddin, 2017). Consumption frequency data was obtained using the Food Frequency Questionnaire (FFQ) which was classified as frequent ( $\geq 3 \mathrm{x} /$ week to daily) and rarely $(\leq 3 \mathrm{x}$ month). The list of food ingredients listed was the result of a focus group discussion (FGD) with 10 students and observations of the school canteen.

The data obtained was tested for normality using the Kolmogorov-Smirnov. Descriptive statistical analysis was used to provide an overview of the characteristics of respondents, while inferential statistical analysis was used to analyze the relationship between the independent and the 


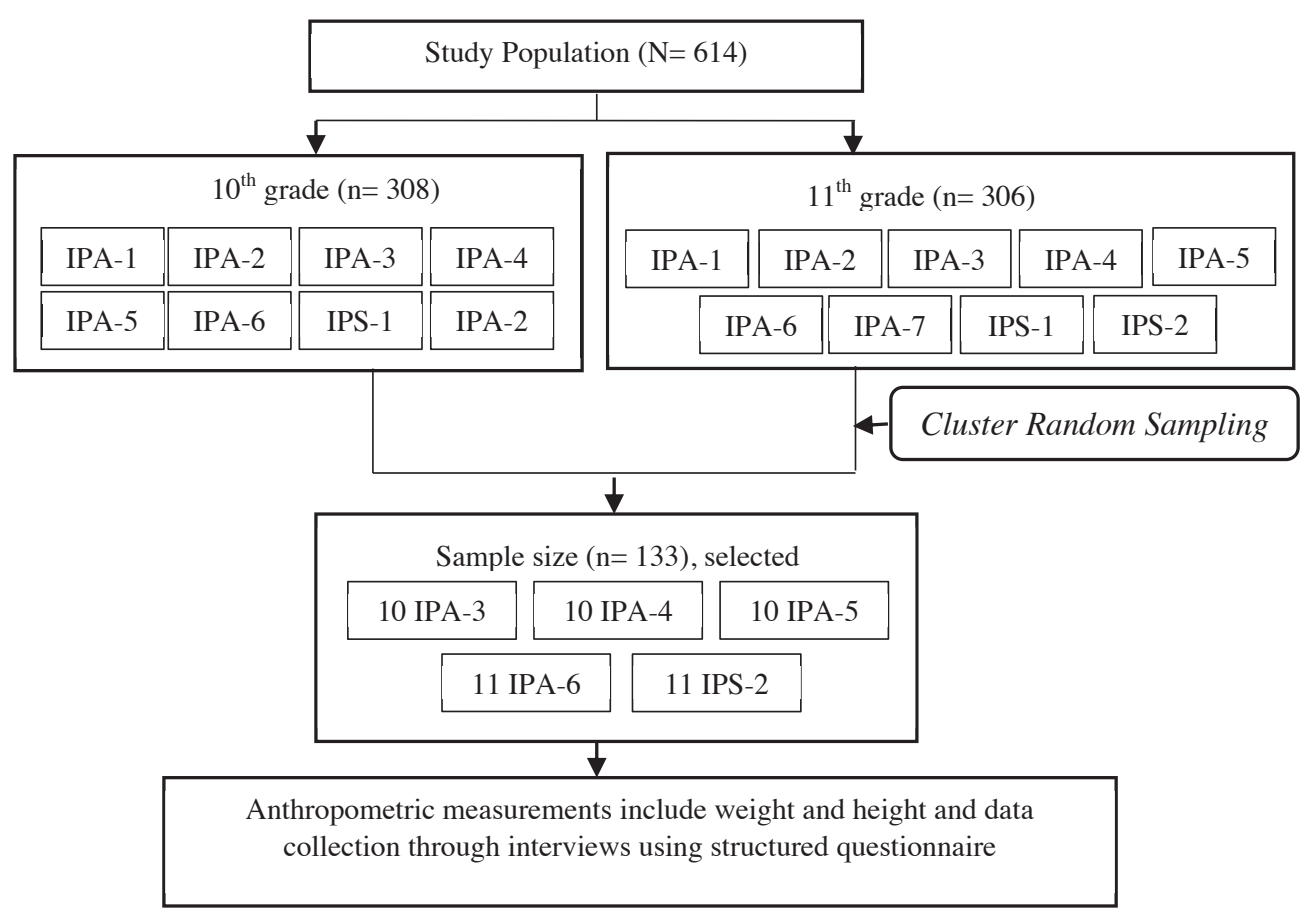

Figure 1. Sample selection flowchart

dependent variable using the Spearman correlation test with a significance value $\mathrm{p}<0.05$; means that there is a relationship between variables. This research has obtained a certificate of research ethics from the Faculty of Nursing, Universitas Airlangga No. 1330-KEPK.

\section{RESULT AND DISCUSSION}

The results showed that $62.4 \%$ of respondents were girls. Respondents are students in grade 10

Table 1. Respondents' characteristics

\begin{tabular}{lcc}
\hline \multicolumn{1}{c}{ Variable } & $\mathbf{n}$ & $\mathbf{\%}$ \\
\hline Gender & & \\
Boys & 50 & 37.6 \\
Girls & 83 & 62.4 \\
Age (years old) & & \\
15 & 15 & 11.3 \\
16 & 77 & 57.9 \\
17 & 41 & 30.8 \\
Grade & & \\
$10^{\text {th }}$ & 78 & 58.6 \\
$11^{\text {th }}$ & 55 & 41.4 \\
Nutritional status & & \\
Very thin & 2 & 1.5 \\
Thin & 7 & 5.3 \\
Normal & 96 & 72.2 \\
Overweight & 19 & 14.3 \\
Obese & 9 & 6.8 \\
\hline
\end{tabular}

$(58.6 \%)$ and grade $11(41.4 \%)$ who are in the middle adolescence age range, between 15-17 years (Brown, et al., 2013) with a maximum age of 16 years $(57.9 \%)$. In adolescence, a person experiences emotional instability that is greater than that of adulthood (Bailen, et al., 2018).

Based on the nutritional status category (BMI ( A), most of the adolescents were having normal nutritional status $(72.2 \%)$. Nineteen adolescents $(14.3 \%)$ were overweight and 9 adolescents (6.8\%) were obese. These results are greater than the national prevalence where there were of $9.5 \%$ adolescents with overweight and $4 \%$ with obesity, and higher than the prevalence in East Java, where $11.3 \%$ of adolescents ware overweight and $5.1 \%$ were obese (Indonesia MoH, 2018).

The results showed that most of the respondents' fathers were private employees (39.1\%), while most of the respondents' mothers did not work (41.4\%). The majority of the respondent's father and mother's last education was high school and equivalent. The economic status of the family can be measured by the income of the parents which is the sum of the income of the respondent's parents. Parents' income can determine the fulfillment of family needs, including determining the quality and quantity of food (Rachman, et al., 2017). It is known that 
Table 2. Parents characteristics and socioeconomic status

\begin{tabular}{|c|c|c|}
\hline Variable & $\mathbf{n}$ & $\%$ \\
\hline \multicolumn{3}{|l|}{ Father's occupation } \\
\hline Government employee & 15 & 11.3 \\
\hline Private employee & 52 & 39.1 \\
\hline Traders & 33 & 24.8 \\
\hline Teacher/lecturer & 6 & 4.5 \\
\hline Army/policeman & 8 & 6.0 \\
\hline Physician & 2 & 1.5 \\
\hline Etc. & 17 & 12.8 \\
\hline \multicolumn{3}{|l|}{ Father's last education } \\
\hline Elementary school & 1 & 0.8 \\
\hline Junior high school & 2 & 1.5 \\
\hline Senior high school & 62 & 46.6 \\
\hline D1/D2/D3 (Diploma) & 8 & 6.0 \\
\hline S1/D4 (Bachelor degree) & 49 & 36.8 \\
\hline S2 (Master degree) & 10 & 7.5 \\
\hline S3 (Doctoral degree) & 1 & 8.0 \\
\hline \multicolumn{3}{|l|}{ Mother's occupation } \\
\hline Not working & 55 & 41.4 \\
\hline Government employee & 5 & 3.8 \\
\hline Private employee & 27 & 20.3 \\
\hline Traders & 12 & 9.0 \\
\hline Teacher/lecturer & 1 & 0.8 \\
\hline Army/policeman & 1 & 0.8 \\
\hline Physician & 2 & 1.5 \\
\hline Etc. & 30 & 22.6 \\
\hline \multicolumn{3}{|l|}{ Mother's last education } \\
\hline Elementary school & 3 & 2.3 \\
\hline Junior high school & 5 & 3.8 \\
\hline Senior high school & 68 & 51.1 \\
\hline D1/D2/D3 (Diploma) & 6 & 4.5 \\
\hline S1/D4 (Bachelor degree) & 46 & 34.6 \\
\hline S2 (Master degree) & 5 & 3.8 \\
\hline S3 (Doctoral degree) & 0 & 0.0 \\
\hline \multicolumn{3}{|l|}{ Family socioeconomic status } \\
\hline Quintile $1(\leq$ IDR 3,510,000) & 33 & 24.8 \\
\hline $\begin{array}{l}\text { Quintile } 2 \text { (>IDR 3,510,000 - } \\
\geq 5,000,000)\end{array}$ & 39 & 29.3 \\
\hline $\begin{array}{l}\text { Quintile } 3 \text { (IDR > Rp. } \\
5,000,000-\geq 9,210 ., 000)\end{array}$ & 28 & 21.1 \\
\hline $\begin{array}{l}\text { Quintile } 4 \text { (IDR > Rp. } \\
9,210,000)\end{array}$ & 33 & 24.8 \\
\hline
\end{tabular}

$29.3 \%$ of parents' income is in the range of IDR $3,510,000-\geq$ IDR 5,000,000 (Table 2).

Based on Table 3, it is known that almost half of the respondents experienced moderate academic stress, as much as $47.4 \%$ and it is known that $23.3 \%$ of adolescents experienced high levels of academic stress. This results in line with the research conducted at SMAN 10 Padang, West Sumatra which reported that 23\%
Table 3. Academic stress level

\begin{tabular}{lcc}
\hline \multicolumn{1}{c}{ Stress level } & n & \% \\
\hline High & 31 & 23.3 \\
Moderate & 63 & 47.4 \\
Low & 39 & 29.3 \\
\hline
\end{tabular}

of students experienced high stress (Barseli, et al. 2018). According to Yussof (2010), factors such as too much material to be studied, difficulty in understanding subject matter, a lot of homework, exams, and tight school schedules are considered as pressure by high school students.

Another study revealed that $31.6 \%$ of students were dissatisfied and as many as $40.6 \%$ of students were less confident about the academic scores that had been obtained. In addition, more than half $(50.4 \%)$ of the adolescents agreed with the condition of feeling not good enough, when they failed to meet their own expectations and felt that there was too much work to be done at school. More than a quarter (27\%) of students with high academic stress felt very dissatisfied or dissatisfied with school life, while only $10 \%$ of students with low academic stress felt very dissatisfied or dissatisfied with school life (Kim, et al., 2013).

$30.8 \%$ of students in our study did not feel pressure in learning every day. There are other things that can be a factor of academic stress for students, such as feeling worried about not being able to find a place to continue their education to a higher level (Yussof, 2010). In this study also found that most students gave a neutral response if education and work in the future could provide academic pressure, but there were still $24.8 \%$ of students agreeing and $24.8 \%$ of students disagreeing with these conditions.

Hassan, et al. (2017) stated that the environment is the main factor that causes stress on students. The environment means the social environment such as teacher expectations, parental expectations, and peer pressure. It can also put students under pressure while they are in school stage. As many as $41.4 \%$ of adolescents felt that they had disappointed the teacher if their test or exam results were bad. As many as $53.4 \%$ of adolescents agreed with the condition that they felt they had disappointed their parents when the 
Table 4. Distribution of Respondents' Answers Based on Educational Stress Scale Adolescents (ESSA) Questions

\begin{tabular}{|c|c|c|c|c|c|c|}
\hline No & Question & $\begin{array}{c}\text { Strongly } \\
\text { disagree } \\
(\%)\end{array}$ & $\begin{array}{l}\text { Disagree } \\
(\%)\end{array}$ & $\begin{array}{c}\text { Neutral } \\
(\%)\end{array}$ & $\begin{array}{c}\text { Agree } \\
(\%)\end{array}$ & $\begin{array}{c}\text { Strongly } \\
\text { agree } \\
(\%)\end{array}$ \\
\hline 1 & I am very dissatisfied with my academic grades & 2.3 & 11.3 & 42.1 & 31.6 & 12.8 \\
\hline 2 & I feel that there is too much school work & 1.5 & 6.0 & 26.3 & 34.6 & 31.6 \\
\hline 3 & I feel that there is too much homework & 3.0 & 11.3 & 42.9 & 28.6 & 14.3 \\
\hline 4 & $\begin{array}{l}\text { My future education and work put a lot of academic } \\
\text { pressure on me }\end{array}$ & 4.5 & 24.8 & 38.3 & 24.8 & 7.5 \\
\hline 5 & $\begin{array}{l}\text { My parents cared too much about my academic } \\
\text { grades which put pressure on me }\end{array}$ & 15.0 & 31.6 & 33.1 & 15.8 & 4.5 \\
\hline 6 & I feel a lot of pressure in studying every day & 10.5 & 30.8 & 36.8 & 16.5 & 5.3 \\
\hline 7 & $\begin{array}{l}\text { I feel that there are too many tests or exams in } \\
\text { school }\end{array}$ & 2.3 & 14.3 & 45.9 & 28.6 & 9.0 \\
\hline 8 & $\begin{array}{l}\text { Academic grades are very important to my future } \\
\text { and can even define my entire life }\end{array}$ & 5.3 & 21.1 & 32.3 & 26.3 & 15.0 \\
\hline 9 & $\begin{array}{l}\text { I feel like I let my parents down when my test / } \\
\text { exam results were bad }\end{array}$ & 2.3 & 4.5 & 16.5 & 53.4 & 23.3 \\
\hline 10 & $\begin{array}{l}\text { I feel like I've let my teacher down when my test / } \\
\text { exam results weren't ideal }\end{array}$ & 3.8 & 7.5 & 39.1 & 41.4 & 8.3 \\
\hline 11 & $\begin{array}{l}\text { There was too much competition among classmates } \\
\text { which gave me a lot of academic pressure }\end{array}$ & 2.3 & 13.5 & 51.1 & 21.8 & 11.3 \\
\hline 12 & I always lacked confidence in my academic grades & 6.0 & 11.3 & 32.3 & 40.6 & 9.8 \\
\hline 13 & $\begin{array}{l}\text { It was very difficult for me to concentrate during } \\
\text { lessons }\end{array}$ & 4.5 & 26.3 & 42.9 & 20.3 & 6.0 \\
\hline 14 & $\begin{array}{l}\text { I feel depressed when life doesn't live up to the } \\
\text { standards that I want }\end{array}$ & 3.0 & 22.6 & 37.6 & 27.1 & 9.8 \\
\hline 15 & $\begin{array}{l}\text { When I fail to live up to my own expectations, I } \\
\text { don't feel good enough }\end{array}$ & 2.3 & 10.5 & 21.1 & 50.4 & 15.8 \\
\hline 16 & $\begin{array}{l}\text { I usually can't sleep because I worry that I won't be } \\
\text { able to meet the goals I set for myself }\end{array}$ & 9.0 & 21.8 & 32.3 & 23.3 & 13.5 \\
\hline
\end{tabular}

test or exam results were bad even though it was known that $31.8 \%$ of parents did not really care about the academic scores of the teenagers. Parents play an important role in adolescent development. There is a significant negative relationship between social support from parents and academic stress in adolescents at SMKN 11 Semarang. This means that the higher social support from parents, the lower the academic stress is, and vice versa (Ernawati and Rusmawati, 2015). The relationship between parents and adolescents is the strongest predictor of stress that occurs in adolescents. A good relationship between parents and adolescents can help adolescents cope with stress or problems experienced during this development stage (Yuin and Yacoob, 2018). When students get high pressure from their parents, students also show high levels of anxiety before exams or during exams.
Table 5. Respondents Emotional Eating Behavior

\begin{tabular}{lcc}
\hline Emotional Eating Behavior & n & \% \\
\hline Not emotional eating & 65 & 48.9 \\
Emotional eating & 68 & 51.1 \\
\hline
\end{tabular}

The majority of parents criticized the children by comparing the child's recent performance with the best performance in the class. So that in friendship, there is a sense of competition among classmates (Deb, et al., 2015; Pratiksha and D'Souza, 2018).

Table 5 shows that $51.1 \%$ of students experience emotional eating. Some people use food not because of hunger, but in an attempt to influence their emotions by consuming food to achieve short-term satisfaction from negative feelings, improve mood and minimize uncomfortable feelings. (Kemp, et al., 2013; Ozier, et al., 2008). 
Table 6. Distribution of Respondents' Answers Based on Emotional Eating Questions

\begin{tabular}{|c|c|c|c|c|c|c|}
\hline No & Questions & $\begin{array}{l}\text { Never } \\
(\%)\end{array}$ & $\begin{array}{l}\text { Rarely } \\
(\%)\end{array}$ & $\begin{array}{l}\text { Sometimes } \\
(\%)\end{array}$ & $\begin{array}{c}\text { Often } \\
(\%)\end{array}$ & $\begin{array}{l}\text { Very often } \\
\quad(\%)\end{array}$ \\
\hline 1 & Have the urge to eat when upset & 25.6 & 26.3 & 29.3 & 12.8 & 6.0 \\
\hline 2 & Have the urge to eat when doing nothing & 9.8 & 12.8 & 32.3 & 36.1 & 9.0 \\
\hline 3 & $\begin{array}{l}\text { Have a desire to eat when feeling depressed or } \\
\text { hopeless }\end{array}$ & 30.1 & 35.3 & 21.8 & 9.0 & 3.8 \\
\hline 4 & Have a desire to eat when feeling lonely & 24.8 & 23.3 & 30.1 & 17.3 & 4.5 \\
\hline 5 & $\begin{array}{l}\text { Have the urge to eat when someone lets you } \\
\text { down }\end{array}$ & 49.6 & 30.1 & 12.8 & 6.0 & 1.5 \\
\hline 6 & Have the urge to eat when irritated & 29.3 & 26.3 & 25.6 & 13.5 & 5.3 \\
\hline 7 & $\begin{array}{l}\text { Have the urge to eat when something unpleas- } \\
\text { ant happens }\end{array}$ & 41.4 & 31.6 & 18.0 & 7.5 & 1.5 \\
\hline 8 & $\begin{array}{l}\text { Have the desire to eat when anxious, worried } \\
\text { or tense }\end{array}$ & 43.6 & 21.8 & 12.0 & 11.3 & 11.3 \\
\hline 9 & $\begin{array}{l}\text { Have the urge to eat when something is against } \\
\text { or something is wrong }\end{array}$ & 63.2 & 27.1 & 6.8 & 2.3 & 0.8 \\
\hline 10 & Have the urge to eat when scared & 72.2 & 21.8 & 5.3 & 0.8 & 0.0 \\
\hline 11 & Have the urge to eat when disappointed & 54.9 & 30.1 & 9.0 & 3.0 & 3.0 \\
\hline 12 & $\begin{array}{l}\text { Have the desire to eat when you are emotion- } \\
\text { ally angry }\end{array}$ & 45.1 & 31.6 & 13.5 & 6.0 & 3.8 \\
\hline 13 & Have a desire to eat when bored or restless & 18.8 & 19.5 & 30.8 & 24.8 & 6.0 \\
\hline
\end{tabular}

As many as $36.1 \%$ of students often have the desire to eat when they are not doing anything and as many as $24.8 \%$ of students have the desire to eat when they feel bored or restless. In addition, it is known that $11.3 \%$ of students often and very often have the desire to eat when anxious, worried or tense. This shows that there were students who have a tendency to emotional eating. Teens tend to overeat or consume unhealthy foods to distract them during stressful conditions and consider it a habit (American Psychological Association, 2014). In addition, stress conditions during adolescence also affect eating preferences in adulthood (Handy, et al., 2016). If this condition continues, it will have an impact on health and nutrition, such as obesity.

The Spearman correlation analysis in Table 7 shows that there is a significant relationship between academic stress and emotional eating behavior ( $\mathrm{p}<0.001)$. As many as $64.5 \%$ of students with high academic stress also experienced emotional eating, while only $28.8 \%$ of students with low academic stress experienced emotional eating. Emotional eating behavior is known to have a significant relationship with stress that comes from academic performance factors (Kim and Kye 2017). The same thing was also found in Syarofi's research (2018) which states that there was a significant relationship between emotional eating behavior and the level of stress experienced by regular nutrition students in the fourth year, but only respondents with severe stress levels experience a tendency to behave emotional eating, while respondents with moderate and mild stress do not experience emotional eating. The results of Penaforte's (2016) study conducted on student, using a Three-Factor Eating Questionnaire, also showed a relationship between stress and emotional eating and uncontrolled eating. In addition, students with higher stress levels have higher scores for emotional eating habits.

Figure 2 shows a positive relationship pattern between academic stress and emotional eating behavior, which means that the higher the level of academic stress, the higher the emotional eating behavior. Higher levels of stress are related to eating behavior such as uncontrolled eating, emotional eating, seeking pleasure through food and using food as a reward (Jarvela-Reijonen, et al., 2016). In stressful conditions, cortisol reactivity occurs in response to stress, this is associated with eating behavior, especially consumption of high- 
Table 7. Relationship between Academic Stress with Emotional Eating and Food Consumption Frequency

\begin{tabular}{|c|c|c|c|c|c|}
\hline \multirow[b]{2}{*}{ Variable } & \multicolumn{3}{|c|}{ Academic stress } & \multirow{2}{*}{$\begin{array}{c}\text { Total } \\
{[n(\%)]}\end{array}$} & \multirow[b]{2}{*}{ p-value } \\
\hline & $\begin{array}{c}\text { High } \\
{[n(\%)]}\end{array}$ & $\begin{array}{c}\text { Moderate } \\
{[n(\%)]}\end{array}$ & $\begin{array}{c}\text { Low } \\
{[n(\%)]}\end{array}$ & & \\
\hline \multicolumn{6}{|c|}{ Emotional eating behavior } \\
\hline Not emotional eating & $11(35.5 \%)$ & $32(50.8 \%)$ & $28(71.8 \%)$ & $71(53.4 \%)$ & \multirow{2}{*}{ 0.003* } \\
\hline Emotional eating & $20(64.5 \%)$ & $31(49.2 \%)$ & $11(28.2 \%)$ & $62(46.6 \%)$ & \\
\hline \multicolumn{6}{|l|}{ Vegetables consumption } \\
\hline Often & $2(6.5 \%)$ & $8(12.7 \%)$ & $3(7.7 \%)$ & $13(9.8 \%)$ & \multirow{3}{*}{0.551} \\
\hline Rarely & $29(93.5 \%)$ & $55(87.3 \%)$ & $34(87.2 \%)$ & $118(88.7 \%)$ & \\
\hline Never & $0(0.0 \%)$ & $0(0.0 \%)$ & $2(5.1 \%)$ & $2(1.5 \%)$ & \\
\hline \multicolumn{6}{|l|}{ Fruits consumption } \\
\hline Often & $1(3.2 \%)$ & $5(7.9 \%)$ & $0(0.0 \%)$ & $6(4.5 \%)$ & \multirow{3}{*}{0.103} \\
\hline Rarely & $30(96.8 \%)$ & $58(92.1 \%)$ & $37(94.9 \%)$ & $125(94.0 \%)$ & \\
\hline Never & $0(0.0 \%)$ & $0(0.0 \%)$ & $2(5.1 \%)$ & $2(1.5 \%)$ & \\
\hline \multicolumn{6}{|l|}{ Fast food/canned food } \\
\hline Often & $2(6.5 \%)$ & $9(14.3 \%)$ & $4(10.3 \%)$ & $15(11.3 \%)$ & \multirow{3}{*}{0.702} \\
\hline Rarely & $29(93.5 \%)$ & $54(85.7 \%)$ & $35(89.7 \%)$ & $118(88.7 \%)$ & \\
\hline Never & $0(0.0 \%)$ & $0(0.0 \%)$ & $0(0.0 \%)$ & $0(0.0 \%)$ & \\
\hline \multicolumn{6}{|l|}{ Snack } \\
\hline Often & $1(3.2 \%)$ & $5(7.9 \%)$ & $2(5.1 \%)$ & $9(6.0 \%)$ & \multirow{3}{*}{0.815} \\
\hline Rarely & $30(96.8 \%)$ & $58(92.1 \%)$ & $37(94.9 \%)$ & $125(94.0 \%)$ & \\
\hline Never & $0(0.0 \%)$ & $0(0.0 \%)$ & $0(0.0 \%)$ & $0(0.0 \%)$ & \\
\hline \multicolumn{6}{|l|}{ Sugary food/cake } \\
\hline Often & $8(25.8 \%)$ & $17(27.0 \%)$ & $8(20.5 \%)$ & $33(24.8 \%)$ & \multirow{3}{*}{0.490} \\
\hline Rarely & $23(74.2 \%)$ & $44(69.8 \%)$ & $30(76.9 \%)$ & $97(72.9 \%)$ & \\
\hline Never & $0(0.0 \%)$ & $2(3.2 \%)$ & $1(2.6 \%)$ & $3(2.3 \%)$ & \\
\hline \multicolumn{6}{|l|}{ Milk and its products } \\
\hline Often & $7(22.6 \%)$ & $21(33.3 \%)$ & $9(23.1 \%)$ & $37(27.8 \%)$ & \multirow{3}{*}{0.736} \\
\hline Rarely & $23(74.2 \%)$ & $37(58.7 \%)$ & $27(69.2 \%)$ & $87(65.4 \%)$ & \\
\hline Never & $1(3.2 \%)$ & $5(7.9 \%)$ & $3(7.7 \%)$ & $9(6.8 \%)$ & \\
\hline \multicolumn{6}{|l|}{ Sweet drinks } \\
\hline Often & $2(6.5 \%)$ & $9(14.3 \%)$ & $6(15.4 \%)$ & $17(12.8 \%)$ & \multirow{3}{*}{0.469} \\
\hline Rarely & $29(93.5 \%)$ & $50(79.4 \%)$ & $32(82.1 \%)$ & $111(83.5 \%)$ & \\
\hline Never & $0(0.0 \%)$ & $4(6.3 \%)$ & $1(2.6 \%)$ & $5(3.8 \%)$ & \\
\hline
\end{tabular}

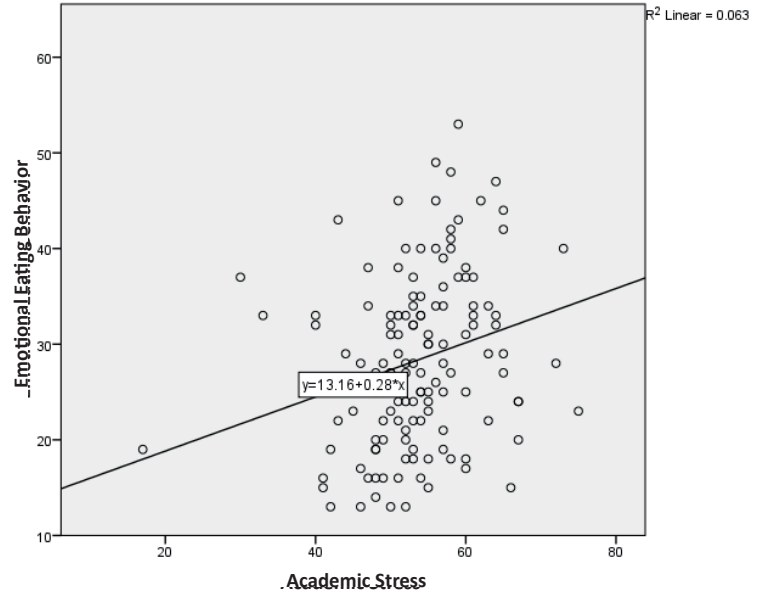

Figure 2. Scatterplot of academic stress and emotional eating behavior

calorie foods. Individuals with a high cortisol reactor to stress conditions, will consume more sweet and high fat foods. It can be said that high stress is associated with increased consumption of unhealthy foods (Cvetovac and Hamar, 2012; Scott and Johnstone, 2012).

In this study, it was found that more than a quarter $(25.8 \%)$ of students who experienced high academic stress ate the sweet food or cake group frequently. Based on the scatterplot, there was a positive pattern between emotional eating behavior with fast food or cans, sweet foods or cakes, milk and its products and sweet drinks. Teens who experience emotional eating have a tendency to consume fast food or cans, sweet foods or cakes, milk and processed products and sweet drinks. Although the relationship with fast food is low. Nguyen, et al., (2007) study describes emotional eating was significantly associated with the frequency of salty high energy-dense, sweet high 
energy-dense, and soda or soft drinks. Everyone has different coping strategy during stress. People with stress conditions tend to eat unhealthy foods, overeat, and some do not experience changes in consumption (Zellner, et al., 2006). However, research by Cvetovac and Hamar (2012) shows that there is a greater positive relationship between consuming more food when stressed as a coping effort than consuming unhealthy foods during stress, even though the results show a positive relationship.

Previous research done by Kim and Kye (2017) also found that adolescents with high stress categories consumed 1.727 times more snacks and the frequency of consuming sweet drinks increased 2.613 times compared to the low stress group. Snacks are usually high in calories and fat but low in fiber. Adolescents with greater stress levels are also associated with increased fat intake (Vidal, 2018).

Another study by Mikolajczyk, et al. (2009) showed that greater stress is associated with higher consumption of carbohydrate-dense foods, such as candy, cakes, snacks, fast food in young women, but not in boys. During adolescence, many adolescents feel that they will not be able to control themselves to consume healthy food when there is a lot of delicious food around them and unhealthy food both at school and / or when they are at home. Only a few adolescents feel able to eat healthy foods (Verstraeten, et al., 2014). According to Thiruselvakumar, et al. (2014), only $18 \%$ of adolescents can control themselves from consuming too much chocolate, candy, and snacks.

There are 4 sources of stress that occur in adolescents, those are intrapersonal, interpersonal, environmental and academic. However, this study has limitations, first is that the source of stress studied was only specific to the source of stress that comes from academics without examining other factors. In addition, this study also did not examine the respondent's daily intake, so it was not possible to know whether the stress variable would affect the respondent's daily intake.

\section{CONCLUSION}

The results showed a relationship between academic stress and emotional eating behavior among adolescents at SMAN 6 Surabaya. It is known that there are still students with high academic stress who have emotional eating behavior and there are students who have the desire to eat when anxious, worried or anxious. The higher the emotional eating score, the higher the tendency to consume fast food or canned food, sweet foods or cakes, milk and its processed products and sweet drinks, although it shows a low positive relationship. Students need to increase student self-efficacy to consume healthy foods in any condition, including stress through nutrition education programs. Further research is needed to collect data on the daily intake of respondents or other negative emotional coping strategy while experiencing academic stress.

\section{ACKNOWLEDGEMENT}

The author would like to thank the vice principal of the public relations department and the students of SMA Negeri 6 Surabaya who gave their time and were willing to become respondents, as well as parents / guardians who gave permission to enroll the study. Enumerators who helped research as well as all related parties who have helped and provided support in this research.

\section{REFERENCES}

Akande., J.A., Olowonirejuaro, A.O., \& OkwaraKalu, C.E. (2014). A Study of level and sources of stress among secondary school students. IOSR Journal of Research \& Method in Education (IOSR-JRME), 4(5), 32-36. Retrieved from: http://www.iosrjournals.org/iosr-jrme/papers/ Vol-4\%20Issue-5/Version-1/E04513236.pdf.

Bailen, N.H., Green, L.M., \& Thompson, R.J., (2018). Understanding emotion in adolescents: a review of emotional frequency, intensity, instability, and clarity. Emotion Review, 1-11. Retrieved from: https://pdfs.semanticscholar.org/ dc61/ ab2cd84a78a78377a01377feeaebf32e37e8. pdf.

Brown, J.E,. Isaacs., J.S., Krinke, U.B., Lechtenberg, E., Murtaugh, M.A., Sharbaugh, C., Splett, P.L., Stang, J., \& Woorldridge, N.H. (2013). Nutrition through the life cycle. (5th ed.). USA: Cengange Learning.

Cvetovac, M. \& Hamar, S. (2012). Stress and Unhealthy Eating in a College Sample. Proceedings of The National Conference On 
Undergraduate Research (NCUR) 2012 Weber State University, Ogden Utah. Retrieved from from: https://pdfs.semanticscholar .org/c2e1/6a 31ed7166a928f710d91f9ac7e95e1feb57.pdf.

American Psychological Association. (2014). Stress and eating. american psychological association. Retrieved from from: https://www.apa.org/ news/press/releases/stress/2013/stress-report. pdf.

Deb, S., Strod, E. \& Sun, J. (2015). Academic stress, parental pressure, anxiety and mental health among Indian High School Students. International Journal of Psychology and Behavioral Sciences, 5(1), 26-34. doi: 10.5923/j. ijpbs.20150501.04.

Finch, L.E., \& Tomiyama L.E. (2015). Comfort eating, psychological stress, and depressive symptoms in young adult women. Appetite, 95, 239-244. doi: 10.1016/j.appet.2015.07.017.

Handy, C., Yanaga, S., Reiss., A., Zona, N., Robinson, E., \& Saxton, K. B. (2016). Stress during adolescence alters palatable food consumption in a context-dependent manner. PLoS ONE, 11(2), 1-13. doi: 10.1371 /journal. pone. 0148261 .

Harvard Medical School. (2018). How stress can make us overeat. Harvard Medical School: Harvard Health Publishing. Retrieved from: https://www.health.harvard.edu/healthbeat/ how-stress-can-make-us-overeat.

Hassan, A.A., Jantan, R. \& Fauzi, M.A.R.M. (2017). Level of stress and anxiety and sources of stress among secondary school students. sci.int. (Lahore), 29(4), 959-963. Retrieved from: http:// www.sci-int.com/pdf/636398815979774997. pdf

Indonesia MoH. (2011). Keputusan Menteri Kesehatan Republik Indonesia Tentang Standar Antropometri Penilaian Status Gizi Anak, Jakarta.

Indonesia MoH. (2018). Laporan Nasional Riset Kesehatan Dasar tahun 2018. Jakarta: Badan Penelitian dan Pengembangan Kesehatan Kemenkes RI.

Jarvela-Reijonen, E., Karhunen, L., Sairanen, E., Rantala, S., Laitinen, J., Puttonen, S., ... Kolehmainen, M. (2016). High perceived stress is associated with unfavorable eating behavior in overweight and obese Finns of working age. Appetite, 103(2), 249-259. doi: 10.1016/j. appet.2016.04.023.

Kemp, E. Bui, M., \& Grier, S. (2013). When food is more than nutrition: Understanding emotional eating and overconsumption. Journal of Consumer Behaviour, 12, 204-213. doi: 10.1002/cb.1413.

Khotibuddin, M. (2017). Hubungan depresi dan perilaku makan terhadap berat badan lebih mahasiswa kedokteran. Mutiara Medika, 17(1), 42-50. Retrived from: http://journal.umy.ac.id/ index.php/mm/article/view/3682.

Kim, S. \& Kye, S. (2017). Effects of daily stress on dietary pattern among elementary school children in Seongnam City. Korean $J$ Community Nutr, 22(6), 475-484. doi: 10.5720/ kjcn.2017.22.6.475.

Mikolajczyk, R.T., Ansari, W.E., \& Maxwell, A.E. (2009). Food consumption frequency and perceived stress and depressive symptoms among students in three European countries. Nutrition Journal, 8:31. doi: 10.1186/14752891-8-31

Murdoch Children's Research Institute. (2015). Transitioning from childhood to adolescence. Retrieved from: https://www.mcri.edu.au/ sites/default/files/media/transitioning-fromchildhood-to-adolescence.

National Eating Disorder Association. (2004). What Causes Eating Disorders?. Retrieved from: https:// www.NationalEatingDisorders.org

Nguyen-Michel, S.T., Unger, J.B., \& Sprtuijt-Metz, D. (2007). Dietary Correlates of Emotional Eating in Adolescence. Appetite, 49(2), 494499. doi: 10.1016/j.appet.2007.03.005

Ozier, A.D., Kendrick, O.W., Leeper, J.D., Knol, L.L., Perko, M., \& Burnham, J. (2008). Overweight and obesity are associated with emotion or stress relating eating and appraisal of ability and resources to cope. Journal of the American Dietetic Association, 108(1), 49-56.

Penaforte, F.R.d.O., Matta, N.C. \& Japur, C.C. (2016). Association between stress and eating behavior in college students. Demetra: Food, Nutrition \& Health, 11(1), 225-237. doi: 10.12957/demetra.2016.1859.

Pratiksha, N \& D'Souza, L. (2018). Academic stress and its influence on academic achievement among early adolescents. The International Journal of Indian Psychology, 6(2), 12-19. Retrieved from: https://www.ijip.in/Archive/ v6i2/18.01.022.20180602.pdf.

Purwanti, M., Putri, E.A., Ilmiawan, I.M., Wilson, W., \& Rozalina., R. (2017). Hubungan tingkat stress dengan indeks massa tubuh mahasiswa PSPD FK UNTAN. Jurnal Vokasi Kesehatan, 3(2), 47-56. Retrieved from: http://ejournal. 
poltekkespontianak.ac.id/index.php/JVK/ article/view/116/.

Rachman, B.N., Mustika, I.G., \& Kusumawati, I.G.A. (2017). Faktor yang berhubungan dengan perilaku konsumsi buah dan sayur siswa SMP di Denpasar. Jurnal Gizi Indonesia (The Indonesian Journal of Nutrition), 6(1), 9-16. Retrieved from: https://ejournal.undip.ac.id/ index.php/jgi/article/view/17749.

Sayekti, E., (2017). Efektifitas teknik self-instruction dalam mereduksi stress akademik pada siswa kelas XI MA YAROBI Kec. Grobogan, Kab. Grobogan Tahun 2016/2017. (Skripsi). Institut Agama Islam Negeri(IAIN), Salatiga. Retrieved from: http://e-repository.perpus.iainsalatiga. ac.id/1634/.

Scott, C. \& Johnstone, A.M. (2012). Stress and eating behaviour: implications for obesity. The European Journal of Obesity, 5(1),277-287. doi:10.1159/000338340.

Sropongwiwat, S., Bunterm, T., \& Tang, K.N. (2017). An investigation of learing stressors among secondary school students: A case study in northeast Thailand. Kasetsart Journal of Social Sciences 39, 197-206. doi: 10.1016/j. kjss.2017.06.002.

Strien, T.V., Frijters, J.E.R., Bergers, G.P.A., \& Defares, P.B. (1986). The Ducth Eating Behavior Questionnaire (DEBQ) for Assessment of Restrained, Emotional, and External Eating Behavior. International Journal of Eating Disorders, 5(2), 295-315. doi: 10.1002/ 1098-108X(198602)5:2<295::AIDEAT2260050209>3.0.CO;2-T.

Subramani \& Kadhiravan. (2017). Academic Stress and Mental Health Among High School Students. Indian Journal and Applied Research, 7(5), 404-406. Retrieved from: https://pdfs. semanticscholar.org/ 2478/6c4fc34572910427 f47fabaa5c51 ade58a29.pdf

Sun, J., Dunne, M.P., Hou, X.Y., \& Xu, A.Q. (2011). Educational stress scale for adolescents: development, validity, and reliability with Chinese students. Journal of Psychoeducational Assessment, 29(6), 534-546. doi: $10.1177 / 0734282910394976$.
Syarofi, Z.N. (2018). Hubungan tingkat stress dan emotional eating dengan status gizi pada mahasiswa program studi S-1 Gizi Reguler Tahun Keempat Universitas Airlangga. (Skripsi). Universitas Airlangga, Indonesia.

Tahir, U. (2016). Stress and eating behaviour. Advances in Obesity, Weight Management \& Control, 4(4), 101-105. doi:10.15406/ aowmc.2016.04.00095.

Tajik, E., Latiffah., A.L., Awang, H, Nur'Asyura, A.S., Chin, Y.S., Shah, A.B.A., Koh, C.H.P., \& Hariz, C.G.M.I. (2016). Unhealthy diet practice and symptoms of stress and depression among adolescents in Pasir Gudang, Malaysia. Obesity Research \& Clinical Practice, 10(2), 114-123. doi: 10.1016/ j.orcp.2015.06.001.

Thiruselvakumar, D., Sinuvasan, K., Sibi, C.R., \& Venkatesh, E. (2014). Factors affecting food choice and attitude of choosing food items among adolescents in South India. International Journal of Scientific and Research Publications, 4(4), 1-3. Retrieved from: http:// http://www.ijsrp.org/research-paper-0414. php?rp=P282566.

Verstraeten, R., Royen, K.V., Ochoa-Aviles, A., Penafiel, D., Holdsworth, M., Donoso, S., ... Kolsteren, P. (2014). A Conceptual framework for healthy eating behavior in ecuadorian adolescents: a qualitative study. PloS ONE, 9(1), 1-7. doi: 10.1371/ journal.pone.0087183.

Vidal, E.J., Alvarez, D., Martinez-Velarde, D, Vidal-Damas L, Yuncar-Rojas K.A., JulcaMalca, A., \& Bernabe-Ortiz, A. (2018) Perceived stress and high fat intake: A study in a sample of undergraduate students. PLoS ONE 13(3): e0192827. doi: 10.1371/ journal. pone. 0192827 .

WHO, 2018. Adolescent development. Retrieved from: https://www.who.int/maternal_child adolescent/topics/adolescence/development/ en/.

Zellner, D.A., Loaiza, S., Gonzales, Z., Pita, J., Morales, J., Pecora, D., \& Wolf. A. (2005). Food selection changes under stress. Physiology \& Behavior, 87, 789-7. doi: 10.1016/ j.physbeh.2006.01.014. 